\title{
Health Status and Access to Health Care Services in Jammu and Kashmir State
}

\author{
Ab Hamid Mir ${ }^{1}$ and Showkat Ahmad Bhat ${ }^{2}$ \\ Assistant Professor (C), Department of Economics, \\ Islamic University of Science and Technology, Awantipora, Jammu and Kashmir, India \\ E-Mail: hamidmir047@gmail.com, showkateco@gmail.com
}

\begin{abstract}
Human capital, as characterized by good education and good health is an important determinant of economic growth. Health finds a predominant place in three of the eight goals, eight of the sixteen targets and eighteen of the fortyeight indicators of the "Millennium Development Goals of the United Nation". Health is the most important social service sector having direct correlation with the welfare of the human being. This sector assumes focus for reaping the demographic dividend having healthy productive workforce and general welfare of a State. The State of Jammu and Kashmir has performed relatively well in providing health and medical facilities to the people, but the level is still beneath the satisfaction. The progress of health infrastructure in the State can be judged by the health infrastructure i.e., the availability of hospitals, dispensaries and doctors. There are 4433 Govt. Health institutions at primary, secondary and tertiary levels with 6674 doctors in-position. The doctor patient ratio in our State is 1:1880 as against the recommendations of World Health Organization (WHO) of 1:1000. The doctor patient ratio at the National level is 1:2000. Besides, 826 sub-centers, 371 New Type Primary Health Centers (NTPHCs) and 87 ISM dispensaries have been sanctioned recently. Further, 1443 Specialists, MBBS/AYUSH doctors and 5494 paramedics have been hired on contract basis under National Health Mission (NHM) respectively. The Bed Capacity of different hospital under GMC Srinagar /Jammu and its associate hospitals in the State is 12965 comprising of 6967 in Kashmir and 5998 in Jammu regions. Most of the health indices of the Jammu and Kashmir are far better as compared to all India level. This is especially a case with life expectancy, Crude Birth Rate, Crude Death Rate, Infant Mortality Rate and Institutional Births. Keywords- Health, Sex Ratio, Nutrition, Water Supply, Sanitation.
\end{abstract}

\section{INTRODUCTION}

Health is an essential input for the development of humans. The health status of the population reflects a crucial aspect of human development i.e. physical and mental capacity which combined with appropriate skill and competence, forms valuable human capital of a nation. Human being, the essence of all development strategies, health constitutes an integral and essential component of the overall social and economic development strategy. As development cannot be measured in economic terms alone, the ultimate goal of development is the improvement in quality of life and the best feasible satisfaction of human needs through basic health care, safe drinking water, sufficient food, sanitation etc. In order to determine the health status in a society, the relevant variables would be the expectation of life at birth, the mortality rates particularly the infant mortality rate (IMR) and the prevalence of various health facilities particularly the number of doctors and paramedical staff, the health institutions like hospitals, health centers and the public health facilities.

\section{HEALTH CARE SERVICES AND HEALTH INDICES IN JAMMU AND KASHMIR}

In Jammu and Kashmir State, "Health Care Services" is important not only for human resource development, but also for restoring the faith of the people in the institutions of governance. The main thrust of these services includes; delivery in the areas of preventive, promotive and rehabilitative health care services at primary, secondary and tertiary level. Primitive health care system inherited from the independence period has undergone enormous changes in establishing advanced network of health delivery system of the State.

Initially it was seen that the health status of the people in the State was poor due to prevalence of diseases of various kinds resulting in morbidity and mortality. This was specially so with respect to women and children. The constraints in the improvement of health status of the people included lack of financial resources, dearth of technical staff, and inadequate health infrastructure. Therefore, in order to improve the health status and to achieve the objectives of "Health for All", the Government of India enunciated the National Health Policy in 1983. In response to this, the State government initiated a number of programmes and activities through which health and medical services could flow to the needy and gradually achieve the aims and objectives set under the national policy. As a result, some improvement was seen in the health status of the people.

The Jammu and Kashmir State has performed relatively well in providing health and medical facilities to the people, but the level is still beneath the satisfaction. The progress of health infrastructure in the state can be judged by the health infrastructure i.e, the availability of hospitals, dispensaries and doctors. There are 3972 health institutions consisting of 115 District/sub district hospitals, 259 Allopathic and 457 Unani dispensaries and Ayarvadic dispensaries, 412 public health centers, 460 medical AIDS and mobile units, 11 TB centers, 2081 family planning centers and sub centers and 55 leprosy sub centers and leprosy control units in 2010-11. 
As on 31-03-2011, 14165 beds were reported to be available in the health institution showing an increase of 3727 beds from 1999-2000 to 2010-11. The number of doctors has reached to 5573 from 4540 during the same period.

The availability of health institutions indicates that population covered per institution for the year 2010-11 was 3024 compared to 3690 for 1999-2000. While as at National average the population covered per institution was 5159 in 2010-11 which is higher as compared to the State average of 3024. For the year 2010-11, 115 hospital beds were available per lakh of population against the corresponding figures of 112 and 111 for year 1999-2000 and 2000-2001 respectively. The following figures at National average were 90 hospital beds available per lakh of population. Similarly on an average 48 doctors/vaids/hakims were to look after the health related needs of one lakh of population for 2010-11 compared to 47 for the year 1999-2000. While as at National level 58 doctors/vaids/hakims were to look after the health related needs of one lakh of population for 2010-11. In terms of population covered per institution and hospital beds available per lakh of population, Jammu and Kashmir has better position but in terms of doctors/vaids/hakims, it lags behind the National average. Following Table I narrates the position of health care infrastructure in Jammu and Kashmir State.

TABLE I TRENDS IN HEALTH CARE INFRASTRUCTURE IN JAMMU AND KASHMIR STATE

\begin{tabular}{|c|c|c|c|c|c|c|}
\hline $\begin{array}{l}\text { Facility } \\
\text { indicators }\end{array}$ & $\begin{array}{c}\text { Health } \\
\text { Institutions }\end{array}$ & $\begin{array}{l}\text { Population covered } \\
\text { per institution }\end{array}$ & $\begin{array}{c}\text { Beds } \\
\text { available }\end{array}$ & $\begin{array}{l}\text { Beds available Per } \\
\text { lakh of population }\end{array}$ & Doctors & $\begin{array}{c}\text { Doctors Available per } \\
\text { lakh of population }\end{array}$ \\
\hline $1999-2000$ & 3656 & 3690 & 11274 & 112 & 4821 & 47 \\
\hline $2000-01$ & 3656 & 3594 & 11921 & 111 & 4821 & 47 \\
\hline 2001-02 & 3692 & 3491 & 12177 & 109 & 4532 & 47 \\
\hline $2002-03$ & 3692 & 2903 & 12177 & 113 & 5101 & 48 \\
\hline 2003-04 & 3735 & 2938 & 12566 & 115 & 5101 & 49 \\
\hline 2004-05 & 3802 & 2963 & 12580 & 112 & 5105 & 47 \\
\hline $2005-06$ & 3698 & 3127 & 12855 & 111 & 5239 & 48 \\
\hline 2006-07 & 3705 & 3204 & 12855 & 108 & 5150 & 46 \\
\hline 2007-08 & 3603 & 3204 & 13744 & 108 & 5294 & 46 \\
\hline 2008-09 & 3657 & 3121 & 12750 & 109 & 5504 & 47 \\
\hline $2009-10$ & 3690 & 3125 & 12932 & 113 & 5573 & 48 \\
\hline $2010-11$ & 3972 & 3024 & 14165 & 115 & 5573 & 48 \\
\hline 2011-12 & 3850 & 3080 & 13578 & 108 & 6255 & 49 \\
\hline $2012-13$ & 3856 & 3080 & 14545 & 116 & 6278 & 50 \\
\hline 2013-14 & 3858 & 3080 & 15536 & 124 & 7992 & 60 \\
\hline $2014-15$ & 4433 & 3546 & 12965 & 104 & 6674 & 53 \\
\hline
\end{tabular}

Besides that, considerable achievements have been made to improve health standards such as life expectancy, child mortality, infant mortality and maternal mortality. The selected health indicators of Jammu and Kashmir and its adjoining States are shown in Table II.

TABLE II SELECTED HEALTH INDICATORS IN JAMMU AND KASHMIR AND ITS ADJOINING STATES

\begin{tabular}{|c|c|c|c|c|c|c|c|c|c|}
\hline $\begin{array}{l}\text { S. } \\
\text { No. }\end{array}$ & $\begin{array}{l}\text { State/ } \\
\text { UT's }\end{array}$ & $\begin{array}{c}\text { Life } \\
\text { expectancy at } \\
\text { Birth } \\
\text { (years) } \\
\end{array}$ & $\begin{array}{c}\text { Crude } \\
\text { Birth } \\
\text { Rate } \\
\text { (CBR)* }\end{array}$ & $\begin{array}{c}\text { Crude } \\
\text { Death } \\
\text { Rate } \\
(\text { CDR })^{*} \\
\end{array}$ & $\begin{array}{c}\text { Total } \\
\text { Fertility } \\
\text { Rate } \\
(\text { TFR) } \\
\end{array}$ & $\begin{array}{c}\text { Infant } \\
\text { Mortality } \\
\text { Rate } \\
\text { (IMR)* }\end{array}$ & $\begin{array}{c}\text { Couple } \\
\text { Protection } \\
\text { Rate } \\
(\text { CPR) \% } \\
\end{array}$ & $\begin{array}{c}\text { Institutional } \\
\text { Births } \\
(\%)\end{array}$ & $\begin{array}{c}\text { Full } \\
\text { Immunization } \\
(\%)\end{array}$ \\
\hline 1 & 2 & 3 & 4 & 5 & 6 & 7 & 8 & 9 & 10 \\
\hline 1 & All India & 66.1 & 17.0 & 5.4 & 2.3 & 34 & 46.6 & 78.9 & 62 \\
\hline 2 & $\mathrm{~J} \& \mathrm{~K}$ & 70.1 & 11.9 & 4.4 & 1.7 & 24 & 15.9 & 85.7 & 75.1 \\
\hline 3 & Delhi & 71.0 & 15.6 & 4.0 & 1.6 & 18 & 24.9 & 85.4 & 66.4 \\
\hline 4 & Punjab & 69.3 & 14.1 & 5.1 & 1.7 & 21 & 56.5 & 90.5 & 89.1 \\
\hline 5 & Himachal & 70 & 10.5 & 7.0 & 1.7 & 25 & 50.5 & 76.4 & 69.9 \\
\hline 6 & Haryana & 67 & 18.3 & 5.1 & 2.3 & 33 & 43.3 & 85.5 & 62.2 \\
\hline 7 & U.P & 62.7 & 22.8 & 5.5 & 1.9 & 43 & 36.0 & 67.8 & 51.1 \\
\hline
\end{tabular}

Source: Family Welfare Statistics in India 
Most of the health indices of the Jammu and Kashmir are far better as compared to all India level. This is especially a case with life expectancy, Crude Birth Rate, Crude Death Rate, Infant Mortality Rate and Institutional Births.

In comparison to its adjoining States, Jammu and Kashmir fairs poorly with Delhi in all health parameters whereas it is at a better position as compared to Uttar Pradesh and Haryana. Punjab and Himachal Pradesh are also comparatively better than Jammu and Kashmir. Couple Protection Rate (CPR) in Jammu and Kashmir State is very low as compared to National level and its other adjoining states. The main reason of the low Couple Protection Rate is that the traditional attitudes against Family Planning are still a big barrier against the universal or large scale use of birth control devices.

These aggregate indicators reflect a satisfactory picture of the health status of Jammu and Kashmir, but to assume on this basis that the public health delivery system of Jammu and Kashmir is well functioning machinery would be misleading. Though the State is ahead of all India level in certain indicators, but it compares poorly viz-à-viz many States of northern India. Judged in terms of the best performing States, Jammu and Kashmir lags far behind. Despite these networks of health institutions in the State, it appears that much progress has not been made in providing the basic health care services to the masses particularly in the rural areas of the State. So much need is to be done in the expansion of basic health care facilities particularly in rural areas.

\section{MAJOR HEALTH INDICATORS}

Health indicators reflect the socio-economic development of the State. In order to live up to this essence, the State government has been putting in serious efforts to increase the level/reach of medical facilities to all within the State despite lot of constraints like difficult terrain, problem of inaccessibility, poor road connectivity, limited presence of private sector/NGOs. While comparing the health indicators of the State with the National average, it is quite evident that the State has performed well on most of the parameters. However, still a lot more needs to be done by providing accessible, acceptable and affordable healthcare services to the people of the State. Following are the health indicators which reflect the commitment of the State regarding health care facilities.

\section{A. Sex Ratio}

The child sex ratio ( 0 to 6 years) has shown a sharp decline from 941 in 2001 to 859 as per census 2011. The overall sex ratio has also declined from 892 in 2001 to 883 as per census 2011. The major efforts are being done like organizing seminars, camps, awaking the people about the consequences of imbalance in the population, strict enforcement of PC\&PNDT Act in the State, with the sole objective to boost the sex ratio of the State in the coming years. Some of the reasons to the low sex ratio are differences in sex ratio at birth, male sex-preference and discrimination of female sex, hard work for females particularly among lower income groups which constitute the bulk of the population, nutrition and house accommodation. Medical facilities, female literacy, per capita income and other social, economic and psychological problems of females in the society due to the poor status of women are also the reasons of low sex ratio in the State.

\section{B. Life Expectancy at Birth}

As per census 2011, the Life Expectancy of males and females at National level stands at 63.95 and 67.08 years, respectively. As far as, the Jammu and Kashmir State is concerned, the life expectancy of males and females stands at 66.5 and 69.3 years, respectively which is more than the National average. Further, the Ministry of Health and Family Welfare, Government of India, for the period 201115 , has launched various health related activities with the main objective of increasing the life expectancy at birth to 67.3 years for male and 69.6 years for female. The average life span has increased over the years in the country as well as in the State which reveals decrease in death rate and improvement in the quality of health services.

\section{Crude Death Rate (CDR)}

The crude death rate (CDR) of the Jammu and Kashmir State is 5.5 which is quite low as compared to national average of 7.1 , as per census 2011. While studying the pattern of CDR from 2006-2011, it reveals that the performance of the State is in line with the National level scenario which has dipped by 0.4 points during the period. The CDR of Jammu and Kashmir State is far better than states like Himachal Pradesh (6.7), Punjab (6.8) and Haryana (6.5).

\section{Infant Mortality Rate (IMR)}

The health system in the State has dramatically changed from what it was a decade ago. Infant Mortality Rate which indicates the death of children before the age of one year per thousand live births is sensitive indicator of the health and nutritional status of population. Reducing Infant Mortality Rate (IMR) is the major objective of National Health Mission (NHM). The State has achieved a significant improvement in the IMR over the period. The IMR has fallen from 52 in 2006 to 37 in 2014.

The Infant Mortality Rate (IMR) of the State is showing a consistent downward trend and is indicative of execution of host of child health related programmes and activities undertaken by the department especially under NRHM since 2006. No doubt, the Infant Mortality Rate of the State has declined over the years; it still requires stringent measures to be adopted in order to achieve the goal of Infant Mortality Rate less than 30 in coming years. 


\section{NUTRITIONAL STATUS}

Food is very important factor that has an impact on woman's health. A healthy mother can give birth to a healthy child. A woman who eats balanced diet does not suffer from severe anaemia. Anaemia is a major health problem in State, especially among women and children. More than half of women in Jammu and Kashmir (52 percent) have anaemia, including 37 percent with mild anaemia, 13 percent with moderate anaemia, and 2 percent with severe anaemia. However, only 27.6 percent women in Jammu \& Kashmir were found to be taking IFA for at least 90 days.

Children's nutritional status in Jammu \& Kashmir has improved since NFHS-3 by all the three measures. Stunting decreased from 35 percent to 27 percent in the 10 years between NFHS-3 and NFHS-4, and the percentage of children who are underweight decreased from 26 percent to 17 percent. However, in the same period, wasting declined only marginally from 15 percent to 12 percent. Despite the gains in stunting, and underweight, child malnutrition is still a major problem in Jammu \& Kashmir.

Among adults' nutritional status, more than two-fifths of women $(41 \%)$ and 32 percent of men are either too thin or overweight or obese. More women and men are overweight or obese than thin, which is opposite to the pattern observed in NFHS-3. Among women age 15-49, the proportion overweight or obese is 29 percent, which is considerably higher than a decade ago (17\% in NFHS-3). Twelve percent each of women and men are too thin and 21 percent of men are overweight or obese. Almost three-fifths of women (59\%) and 68 percent of men are at a healthy weight for their height.

The use of iodized salt prevents iodine deficiency, which can lead to miscarriage, goitre, and mental retardation. Ninety-six percent of Jammu \& Kashmir's households were using iodized salt at the time of the survey, a higher proportion (91\%) than reported in NFHS-3.

\section{WATER SUPPLY}

The water sector is facing daunting challenges due to urbanization, industrialization and huge demand for Agriculture sector. The potential for augmentation of supply is limited, water tables are falling and water quality issues have increased. Our rivers and ground waters are continuously polluted by untreated effluents and sewerage. The climate change poses fresh challenges.

As per Survey 2003, there were 12015 rural habitations in the Jammu and Kashmir State. Besides there are 3763 habitations which have emerged over the years making the total number of habitations to 15778 ending 2014.

The criteria for coverage of habitations have been enhanced from present 40 LPCD to 55 LPCD. All new schemes are being designed with minimum supply level of 55 LPCD.
The status of rural habitations covered under drinking water schemes is given in Table III as under

TABLE III STATUS OF RURAL HabitATIONS OF J\&K

\begin{tabular}{|l|c|c|}
\hline \multicolumn{1}{|c|}{ Status } & J\&K State (1-4-2014) & \%age \\
\hline 100\% covered & 8049 & 51.01 \\
\hline between $75 \%$ and $100 \%$ & 1057 & 6.69 \\
\hline between $50 \%$ and $75 \%$ & 4570 & 28.96 \\
\hline between $25 \%$ and $50 \%$ & 1615 & 10.23 \\
\hline between $0 \%$ and $25 \%$ & 497 & 3.14 \\
\hline Total Source: Economic Survey of J\&K, 2013-14 \\
\hline \multicolumn{2}{|c|}{}
\end{tabular}

From the year 2013-14, the criteria for measurement of availability of drinking water has been changed from litre per capita per day (LPCD) to percentage of population covered with $40 \mathrm{lpcd}$. The physical progress of rural habitations up to date indicates that $51.01 \%$ habitations have been fully covered and $49.99 \%$ have been partially covered.

To address the drinking water problem in the State, a number of schemes are being also implemented under State Plan/District Plan, LIC/NABARD loan assistance and Economic Reconstruction Agency. India is committed to provide safe drinking water facilities and sanitation to all.

\section{SANITATION}

Sanitation coverage, which ought to be a way of life to safeguard health, is inadequate in Jammu and Kashmir State. Access to sanitation facilities is still a challengealmost 50 percent of households have no toilets. Furthermore, the practice of open defection in Jammu and Kashmir State remains a major challenge.

In India, only 50 per cent of households had access to sanitation facilities. In Jammu and Kashmir State 50 per cent of households were without toilets, and thus there was a greater possibility of open defection in the state. The proportion of households with toilet facilities was significantly higher in urban areas (85.5 percent) than rural areas. It should be noted that in rural India as many as 61.5 per cent of households were without toilets. Thus, it is not surprising that in the rural areas the population has many health problems.

An important area of intervention in the Jammu and Kashmir State is to provide sanitary facility at each household and at each corner of the district. This obviously reduces health hazards and at the same time ensures better standard of living of the people. More than a decade ago the State took a leading role in launching Total Sanitation Campaign (TSC) in the State, but the State has not yet achieved to bring all the households under the coverage of sanitary facility. The campaign is targeted to be completed up to the year 2015 is shown in Table IV. 
TABLE IV: SHARING PATTERN OF ALL THE COMPONENTS

\begin{tabular}{|c|c|c|c|c|}
\hline 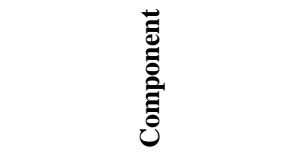 & 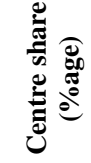 & 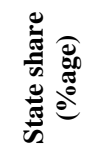 & 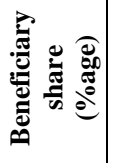 & 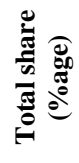 \\
\hline $\begin{array}{l}\text { Individual Household } \\
\text { Latrines }\end{array}$ & 66.67 & 23.33 & 10 & 100 \\
\hline School Toilets & 70 & 30 & - & 100 \\
\hline $\begin{array}{l}\text { Community Sanitary } \\
\text { Complex }\end{array}$ & 60 & 30 & 10 & 100 \\
\hline Anganwadi Units & 70 & 30 & - & 100 \\
\hline Rural Sanitation Mart & 80 & 20 & - & 100 \\
\hline
\end{tabular}

The total project objective under this component is 1270803 units (567732 units for APL \& 703071 units for BPL), out of which 537240 IHHLs (189397 for APL and 347843 for BPL) were completed up to December, 2013 and the balance target is proposed to be covered during the 12th Five Year Plan period.

\section{CONCLUSION}

The health condition is assessed by using a set of indicators on which reasonable and reliable data are available that reflect various dimensions of health. This includes indicators of mortality, morbidity and nutritional status called "Health Outcomes" and access to and utilization of preventive, primitive and cultural services broadly called health care.

The Jammu and Kashmir State has performed relatively well in providing health and medical facilities to the people. There are 3972 health institutions consisting of 115 District/sub district hospitals, 259 Allopathic and 457 Unani dispensaries and Ayarvadic dispensaries, 412 public health centers etc in 2010-11. Most of the health indices of the Jammu and Kashmir are far better as compared to all India level. This is especially a case with life expectancy, Crude Birth Rate, Crude Death Rate, Infant Mortality Rate and Institutional Births. As far as, the Jammu and Kashmir State is concerned, the life expectancy of males and females stands at 66.5 and 69.3 years, respectively which is more than the national average. The crude birth rate of the Jammu and Kashmir State is 17.5 which is well below the National average of 21.8. The crude death rate (CDR) of the Jammu and Kashmir State is 5.5 which is quite low as compared to national average of 7.1, as per census 2011. The total fertility rate has come down below the replacement level for the first time in the State to 1.9 in 2014 as compared to 2.3 in 2006, which is quite low when compared with the national average which stands at 2.5 .

The State has achieved a significant improvement in the IMR over the period. The IMR has fallen from 52 in 2006 to 37 in 2014. Neo-natal survival is a very sensitive indicator of population growth and socioeconomic development. The Neo-natal Mortality Rate of the State remained stagnant at
39 during 2006 to 2008 and further declined to 35 in 2010. There has been improvement over time in the proportion of births being delivered safely in Jammu and Kashmir. The percentage of births that were delivered in a health facility increased from 36 percent in NFHS-2 to 54 percent in NFHS-3; and the percentage assisted by a health professional increased in the same seven years from 42 percent to 61 percent. The overall sex ratio in the State has declined from 892 in 2001 to 883 as per census 2011 is the matter of concern. The water sector is facing daunting challenges due to urbanization, industrialization and huge demand for Agriculture sector. Sanitation coverage, which ought to be a way of life to safeguard health, is inadequate in Jammu and Kashmir State. In India, only 50 percent of households had access to sanitation facilities. In Jammu and Kashmir State 50 percent of households were without toilets, and thus there was a greater possibility of open defection in these States.

\section{REFERENCES}

[1] Bhat, M.S. and Misri, M. L. (1994). Poverty, Planning and Economic Change in Jammu and Kashmir, Vikas Publications, New Delhi.

[2] Brijesh C. Purohit. (2012). Poverty, Human Development and Health Financing in India, Working Paper, Madras School of Economics, Chennai.

[3] Census of India. (2011). Analytical Report on Housing Amenities, Office of the Registrar General and Census Commissioner, New Delhi.

[4] Government of India (2010). Human Development in India- Analysis to Action", Planning Commission, Government of India, Yojana Bhawan Parliament Street, New Delhi.

[5] Government of India. (2010). Human Development in India, Challenges for a Society in Transition", Planning Commission, Government of India, Oxford University Press, New Delhi.

[6] Government of India. (2011). India Human Development Report, Towards Social Inclusion", Planning Commission, Government of India, Oxford University Press, New Delhi.

[7] Government of Jammu and Kashmir. (2010-11). Digest of Statistics" issued by Directorate of Economics and Statistics Department of Planning and Development, Govt. of Jammu and Kashmir.

[8] Government of Jammu and Kashmir. (2013). Economic Survey of Jammu and Kashmir, Directorate of Economics and Statistics Department of Planning and Development, Govt. of Jammu and Kashmir.

[9] Government of Jammu and Kashmir. (2015). Economic Survey of Jammu and Kashmir (2014-15), Directorate of Economics and Statistics Department of Planning and Development, Govt. of Jammu and Kashmir.

[10] Government of India. (2005-06). Jammu and Kashmir National Family Health Survey (NFHS-3), Ministry of Health and Family Welfare International Institute for Population Sciences.

[11] Government of J\&K (2007-08). Indicators of Regional Development, Directorate of Economics and Statistics, Department of Planning and Development, Govt. of Jammu and Kashmir.

[12] Government of Jammu and Kashmir. (1998-99). National Family Health Survey, International Institute for Population Sciences, Deonar, Mumbai.

[13] Government of India. (2012). Key Indicators of Drinking Water Sanitation, Hygiene and Housing condition in India, NSS 69th Round (JULY 2012 - December 2012), Ministry of Statistics and programme Implementation, National Sample Survey Office.

[14] Government of India. (2013). SAARC Development Goals, India Country Report, Statistical Appraisal, Central Statistics Office, Ministry of Statistics and Programme Implementation.

[15] Haq, M. (1998), Reflections on Human Development, Oxford University Press, New Delhi.

[16] Khanday, Ahmad, Z. \& Mohd. Akram. (2014).A Study of Health Structure and Health Expenditure Patterns in Anantnag District of 
Jammu and Kashmir, International Journal of Social and Behavioural Sciences, 1(2), 065-076.

[17] Parikh, S., and Radhakrishana R., (2004-05). India Development Report", Oxford University Press, New Delhi.

[18] Singh, J. (2004). The Economy of Jammu and Kashmir, Published by Radha Krishna Anand \& Co, Jammu.

[19] United Nations Development Programme. (1990). Human Development Report, Oxford University Press, Oxford.
[20] World Health Organization, (2009). Women and Health: Today's Evidence Tomorrow's Agenda. Retrieved from http:/whqlibdoc.who.it/publications/2009/9789241563857_eng.pdf (accessed on 5 July 2012).

[21] Yasir M. \& Fayaz B., (2014).Gender, Health and Availability of Health Services in Jammu and Kashmir, International Journal of Applied Sociology, 35-46, Scientific and Academic Publishing. 